\title{
Interaction between antibiotic use and MS4A2 gene polymorphism on childhood eczema: a prospective birth cohort study
}

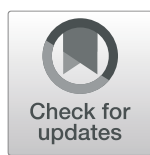

\author{
Li Hua', Qian Chen², Quan-Hua Liu', Yi-Feng Guo ${ }^{3}$, Ru-Hong Cheng ${ }^{3}$, Jun Zhang ${ }^{2}$, Jian-Hua Zhang ${ }^{1}$, \\ Li-Wei Wang $^{1 *}$ and Ruo-Xu Ji ${ }^{* *}$
}

\begin{abstract}
Background: Eczema is usually the first allergic manifestation to appear in life attributed to gene-environment interactions. IL13, IL4, MS4A2 and ILR4A are four key inflammatory genes associated with atopy. This study aimed to explore gene-environment interactions on eczema in early life among the above four genes and environmental factors in Chinese Han children.

Methods: Five hundred ninety-seven children from a birth cohort who completed two-year follow-up were enrolled and their cord blood was collected. Subjects were genotyped for six polymorphisms in the aforementioned four genes. The children were followed at 6, 12 and 24 months, with epidemiologic information and medical history of eczema collected by questionnaire and eczema assessed by dermatologists.

Results: Among the 597 children, 168 were diagnosed with eczema and the others were not after 2 years of follow-up. MS4A2 rs569108 GG genotype $(P=1.68 \mathrm{E}-02$, odds ratio $(\mathrm{OR})=4.66)$ and antibiotic use $(P=3.75 \mathrm{E}-4, \mathrm{OR}=$ 2.02) were found independently associated with development of childhood eczema. Children with both antibiotic use and MS4A2 rs569108 GG genotype were more likely to develop eczema than those with only antibiotic use or $\mathrm{GG}$ homozygote (OR=6.24 VS. 2.04 or 4.68).

Conclusions: MS4A2 rs569108 polymorphism and antibiotic use were solely associated with eczema, and they interacted with each other to increase the risk of developing the disease in Chinese Han toddlers. Long-term follow-up along with functional and replication studies are still needed.
\end{abstract}

Keywords: Eczema, Antibiotic use, Gene, MS4A2, Birth cohort

\section{Introduction}

Eczema, also known as atopic dermatitis, is a common inflammatory skin disease beginning in early life with increasing incidence in many countries around the world $[1,2]$. The high prevalence of eczema is believed to be a result of gene-environment interactions $[3,4]$, which has

\footnotetext{
* Correspondence: wlw0222@163.com; jiruoxu@163.com

'Department of Pediatric Pulmonology, Xin Hua Hospital, Shanghai Jiao

Tong University School of Medicine, 1665 Kongjiang Road, Shanghai 200092, China

Full list of author information is available at the end of the article
}

aroused extensive research interest and led to increasing studies on the risk and protective factors of the disease.

Allergic diseases have long been attributed to IgEmediated inflammatory reactions [5] and eczema is usually the first allergic manifestation to appear in life [6]. In this study, we focused on four key inflammatory genes affecting IgE levels, including IL13, IL4, MS4A2 and ILR4A, which have been associated with atopy [712], and replicated in more than ten different studies [13]. We attempted to explore gene-environment interactions on eczema in early life among the

(c) The Author(s). 2021 Open Access This article is licensed under a Creative Commons Attribution 4.0 International License, which permits use, sharing, adaptation, distribution and reproduction in any medium or format, as long as you give appropriate credit to the original author(s) and the source, provide a link to the Creative Commons licence, and indicate if changes were made. The images or other third party material in this article are included in the article's Creative Commons licence, unless indicated otherwise in a credit line to the material. If material is not included in the article's Creative Commons licence and your intended use is not permitted by statutory regulation or exceeds the permitted use, you will need to obtain permission directly from the copyright holder. To view a copy of this licence, visit http://creativecommons.org/licenses/by/4.0/ The Creative Commons Public Domain Dedication waiver (http://creativecommons.org/publicdomain/zero/1.0/) applies to the data made available in this article, unless otherwise stated in a credit line to the data. 
aforementioned four genes and environmental factors in a birth cohort with a two-year follow-up in Chinese Han population.

\section{Methods}

\section{Study design and participants}

A birth cohort study was carried out at two large tertiary hospitals in Shanghai from 2012 to 2015. One thousand fifty-six women who had a singleton pregnancy and planned to live in Shanghai for at least 2 years were recruited. Trained research nurses conducted face-to-face interviews to collect parental information on atopy, education levels and family income. Newborn's birth information from hospital records along with umbilical cord blood were collected at birth by research nurses. Then the children were followed up for 2 years and their medical history of eczema and epidemiologic information were collected by questionnaire. Five hundred ninetyseven Chinese Han children who completed the 2 years of follow-up were included in this study. Written informed consent was obtained from parents and / or legal guardians for all the subjects who are under 16. This study was approved by the Ethics Committees of the two participating hospitals, Xinhua Hospital and the International Peace Maternity \& Child Health Hospital, and conducted according to the principles in the Declaration of Helsinki.

\section{Questionnaire survey and assessment of eczema}

Each study subject was followed up at 6 months, 1 year and 2 years of age. At six-month follow-up, an internetbased questionnaire survey was conducted to collect children's history of eczema via the standardized International Study of Asthma and Allergies in Childhood (ISAAC) questionnaire, which had been validated and adapted in China [14, 15]. Information on antibiotic use and environmental exposures, including home pet sitting, secondhand smoke exposure and home decoration was also collected. At one-year and two-year follow-up visits, face-to-face questionnaire interviews were conducted to collect similar information as that at sixmonth follow-up.

The diagnostic criteria for eczema were: itchy rash on the flexural sites (the folds of the elbows, behind the knees or in front of the ankles), face, or around the neck or ears, and itchy rash coming and going for at least 6 months, based on the UK working party's diagnostic criteria [16]. Two dermatologists diagnosed eczema independently for all the subjects based on the questionnaires, with disagreements resolved by consensus.

\section{Candidate genes and single nucleotide polymorphisms}

This study focused on four candidate genes, including IL13, IL4, MS4A2 and IL4RA, which are key inflammatory genes associated with IgE levels [7-12]. Within these genes, six known functional single-nucleotide polymorphisms (SNPs) with minor allele frequency greater than $10 \%$ based on Chinese population [17] were chosen for analysis, as shown in Table 1.

\section{Genotyping}

Genomic DNA was obtained from umbilical cord blood with the QIAamp DNA Blood Mini Kit (Qiagen, Hilden, Germany). SNP genotyping was performed using matrixassisted laser desorption / ionization time of flight mass spectrometry (MALDI-TOF MS) [18] (MassArray iPLEX; Sequenom, San Diego, CA, USA). Genotyping call rate for each SNP exceeded 99\%. 5\% of the samples were blindly retested and concordance rate for duplicate genotyping was greater than $98 \%$.

\section{Statistical analysis}

Associations of epidemiologic factors with eczema were assessed by multivariate logistic regression adjusting for potential confounders. Each SNP was tested for HardyWeinberg equilibrium in the study subjects with the $X^{2}$ test, and associations of the SNPs with eczema were also evaluated using multivariate logistic regression. Gene environment interaction on eczema was examined by $x^{2}$ tests. A two-tailed $P$ value of 0.05 or less was considered

Table 1 Candidate genes and SNPs analyzed in this study

\begin{tabular}{|c|c|c|c|c|c|}
\hline Gene & SNP & Chromosome position & Location & Allele $^{a}$ & $\mathrm{MAF}^{\mathrm{b}}$ \\
\hline IL13 & rs20541 & $5: 132660272$ & Exon 4 & $\mathrm{G} / \mathrm{A}$ & $0.34 / 0.20 / 0.20$ \\
\hline $1 / 4$ & rs2243250 & 5:132673462 & Promoter & $\mathrm{T} / \mathrm{C}$ & $0.21 / T, 0.15 / 0.36^{c}$ \\
\hline MS4A2 & rs1441586 & $11: 60088555$ & Promoter & T/C & $0.35 / 0.44 / 0.49$ \\
\hline MS4A2 & rs569108 & 11:60095631 & Exon7 & $A / G$ & $0.18 / 0.03 / 0.17$ \\
\hline ILARA & rs1805010 & 16:27344882 & Exon 5 & $A / G$ & $0.50 / 0.45 / 0.48$ \\
\hline IL4RA & rs1801275 & 16:27363079 & Exon 12 & $A / G$ & $0.18 / 0.20 / A, 0.34^{d}$ \\
\hline
\end{tabular}

SNP single-nucleotide polymorphism, MAF minor allele frequency

${ }^{\text {a }}$ Major/minor allele shown

${ }^{b}$ MAF in this study/Europeans/Africans. MAF in Europeans and Africans was from National Center for Biotechnology Information (https://www.ncbi.nlm.nih.gov/)

${ }^{c}$ Minor allele is $C$ in this study and Africans, but it is $T$ in Europeans

${ }^{d}$ Minor allele is $G$ in this study and Europeans, but it is $A$ in Africans 
Table 2 Associations of epidemiologic factors with eczema

\begin{tabular}{|c|c|c|c|c|}
\hline Phenotypes & $\begin{array}{l}\text { Eczema } \\
\mathrm{n}(\%)\end{array}$ & $\begin{array}{l}\text { Non-eczema } \\
\mathrm{n}(\%)\end{array}$ & $P$ value ${ }^{a}$ & OR $(95 \% \mathrm{Cl})^{b}$ \\
\hline \multicolumn{5}{|l|}{ Gender } \\
\hline Boy & $95(56.9)$ & $212(49.4)$ & & 1 \\
\hline Girl & $72(43.1)$ & $217(50.6)$ & 0.20 & $0.78(0.53,1.14)$ \\
\hline \multicolumn{5}{|l|}{ Gestational age (wk) } \\
\hline$<37$ & $3(1.8)$ & $18(4.2)$ & & 1 \\
\hline $37-39$ & $126(75.0)$ & $293(68.3)$ & 0.44 & $1.84(0.39,8.61)$ \\
\hline$\geq 40$ & $39(23.2)$ & $118(27.5)$ & 0.64 & $1.47(0.30,7.15)$ \\
\hline \multicolumn{5}{|l|}{ Birth weight (g) } \\
\hline$<2500$ & $2(1.2)$ & $14(3.3)$ & & 1 \\
\hline $2500-4000$ & $152(90.5)$ & $377(87.9)$ & 0.44 & $2.07(0.32,13.24)$ \\
\hline$\geq 4000$ & $14(8.3)$ & $38(8.9)$ & 0.48 & $2.04(0.28,14.68)$ \\
\hline \multicolumn{5}{|l|}{ Delivery mode } \\
\hline Vaginal & $44(26.2)$ & $105(24.5)$ & & 1 \\
\hline Cesarean section & $124(73.8)$ & $324(75.5)$ & 0.31 & $0.80(0.51,1.23)$ \\
\hline \multicolumn{5}{|l|}{ Parity } \\
\hline None & $158(94.0)$ & $390(90.9)$ & & 1 \\
\hline$\geq 1$ & $10(6.0)$ & $39(9.1)$ & 0.16 & $0.57(0.26,1.25)$ \\
\hline \multicolumn{5}{|l|}{ Antibiotic use } \\
\hline No & $72(42.9)$ & $255(60.0)$ & & 1 \\
\hline Yes & $96(57.1)$ & $170(40.0)$ & 0.00 & $2.02(1.37,2.98)$ \\
\hline \multicolumn{5}{|l|}{ Home pet sitting ${ }^{c}$} \\
\hline No & $133(79.2)$ & $355(83.5)$ & & 1 \\
\hline Yes & $35(20.8)$ & $70(16.5)$ & 0.51 & $1.18(0.72,1.92)$ \\
\hline \multicolumn{5}{|c|}{ In-home secondhand smoke exposure } \\
\hline No & $66(39.3)$ & $213(50.2)$ & & 1 \\
\hline Yes & $102(60.7)$ & $211(49.8)$ & 0.16 & $1.32(0.89,1.96)$ \\
\hline \multicolumn{5}{|l|}{ Home decoration } \\
\hline No & $152(91.0)$ & $394(92.7)$ & & 1 \\
\hline Yes & $15(9.0)$ & $31(7.3)$ & 0.43 & $1.31(0.67,2.57)$ \\
\hline \multicolumn{5}{|l|}{ Parental atopy ${ }^{d}$} \\
\hline No & $120(72.3)$ & $346(81.6)$ & & 1 \\
\hline Yes & $46(27.7)$ & $78(18.4)$ & 0.06 & $1.53(0.98,2.39)$ \\
\hline \multicolumn{5}{|l|}{ Maternal education } \\
\hline Middle school or lower & $3(1.8)$ & $15(3.5)$ & & 1 \\
\hline High school & $14(8.3)$ & $57(13.3)$ & 0.87 & $1.13(0.24,5.40)$ \\
\hline College or higher & $151(89.9)$ & $356(83.2)$ & 0.43 & $1.81(0.42,7.85)$ \\
\hline \multicolumn{5}{|l|}{ Paternal education } \\
\hline Middle school or lower & $2(1.2)$ & $6(1.4)$ & & 1 \\
\hline High school & $17(10.2)$ & $51(12.0)$ & 0.65 & $0.64(0.09,4.45)$ \\
\hline College or higher & $148(88.6)$ & $367(86.6)$ & 0.44 & $0.48(0.07,3.11)$ \\
\hline \multicolumn{5}{|l|}{ Family income (CNY) } \\
\hline$<100 \mathrm{~K}$ & $44(26.3)$ & $129(30.2)$ & & 1 \\
\hline$\geq 100 \mathrm{~K}$ & $101(60.5)$ & $226(52.9)$ & 0.24 & $1.32(0.84,2.08)$ \\
\hline Unknown & $22(13.2)$ & $72(16.9)$ & 0.77 & $0.91(0.49,1.70)$ \\
\hline
\end{tabular}

OR odds ratio, $\mathrm{Cl}$ confidence interval

a $P$ Values were tested by multivariate logistic regression

${ }^{b}$ All parameter estimates were adjusted for other covariates

${ }^{c}$ keeping cats or dogs at home
${ }^{d}$ Parental atopy was referred to those parents who had asthma, allergic rhinitis or atopic dermatitis along with detectable specific lgE 
Table 3 Associations of candidate genes with eczema

\begin{tabular}{|c|c|c|c|c|}
\hline Genotypes & $\begin{array}{l}\text { Eczema } \\
\text { n (\%) }\end{array}$ & $\begin{array}{l}\text { Non-eczema } \\
\text { n (\%) }\end{array}$ & $P$ value $^{a}$ & OR $(95 \% \mathrm{Cl})$ \\
\hline \multicolumn{5}{|l|}{ IL13 rs20541 } \\
\hline $\mathrm{AA}$ & $13(7.7)$ & $52(12.1)$ & & 1 \\
\hline$A G$ & $79(47.0)$ & $197(46.0)$ & 0.13 & $1.70(0.86,3.36)$ \\
\hline GG & 76 (45.2) & 179 (41.8) & 0.10 & $1.77(0.90,3.49)$ \\
\hline \multicolumn{5}{|l|}{ IL4 rs2243250 } \\
\hline CC & $8(4.8)$ & $21(4.9)$ & & 1 \\
\hline $\mathrm{CT}$ & $55(32.7)$ & 137 (31.9) & 0.73 & $1.17(0.48,2.88)$ \\
\hline$\pi$ & $105(62.5)$ & $271(63.2)$ & 0.83 & $1.10(0.46,2.62)$ \\
\hline \multicolumn{5}{|c|}{ MS4A2 rs1441586 } \\
\hline $\mathrm{CC}$ & $20(11.9)$ & $46(10.8)$ & & 1 \\
\hline CT & $70(41.7)$ & $212(49.8)$ & 0.73 & $1.14(0.53,2.46)$ \\
\hline$\pi$ & $78(46.4)$ & $168(39.4)$ & 0.41 & $1.42(0.61,3.30)$ \\
\hline \multicolumn{5}{|c|}{ MS4A2 rs569108 } \\
\hline AA & $120(71.4)$ & $285(66.4)$ & & 1 \\
\hline$A G$ & 38 (22.6) & 137 (31.9) & 0.26 & $0.74(0.44,1.25)$ \\
\hline GG & $10(6.0)$ & $7(1.6)$ & 0.02 & $4.66(1.32,16.44)$ \\
\hline \multicolumn{5}{|c|}{ IL4RA rs 1805010} \\
\hline AA & $44(26.3)$ & 109 (25.6) & & 1 \\
\hline$A G$ & 79 (47.3) & $209(49.1)$ & 0.82 & $0.95(0.61,1.49)$ \\
\hline GG & $44(26.3)$ & $108(25.4)$ & 0.67 & $1.12(0.67,1.88)$ \\
\hline \multicolumn{5}{|c|}{ IL4RA rs 1801275} \\
\hline AA & $107(63.7)$ & $288(67.3)$ & & 1 \\
\hline$A G$ & $59(35.1)$ & $127(29.7)$ & 0.10 & $1.41(0.94,2.10)$ \\
\hline GG & $2(1.2)$ & $13(3.0)$ & 0.25 & $0.41(0.09,1.86)$ \\
\hline
\end{tabular}

$O R$ odds ratio, $\mathrm{Cl}$ confidence interval

a $P$ Values were tested by multivariate logistic regression

statistically significant. All analyses were performed using SPSS version 17.0 (IBM Corp., Armonk, NY, USA).

\section{Results}

Associations of epidemiologic factors with eczema

Among the 597 children, 168 were diagnosed with eczema after 2 years of follow-up while the others were not. Characteristics of the study subjects were presented in Table 2. Antibiotic use was found significantly associated with development of childhood eczema after adjusting for multiple child and parental characteristics $(P=3.75 \mathrm{E}-4$, odds ratio $(\mathrm{OR})=2.02)$. However, baby's gender, gestational age, birth weight, delivery mode, parity, home pet sitting, in-home secondhand smoke exposure, home decoration, family income, parental atopy and education level were not found associated with eczema by multivariate logistic regression $(P>0.05)$.

\section{Associations of candidate genes with eczema}

All the SNPs met Hardy-Weinberg equilibrium criteria $(p>0.05)$. The genetic models (additive, dominant and recessive models) were tested for the SNPs. Among the six SNPs, only MS4A2 rs569108 was found associated with childhood eczema $(\mathrm{P}<0.05)$, and its most significant association with the disease was under additive model. Association test results under additive model were shown in Table 3. MS4A2 rs569108 GG genotype was found significantly associated with eczema $(P=1.68 \mathrm{E}-02, \mathrm{OR}=4.66)$. No significant associations were found between the other five SNPs and eczema $(P>0.05)$.

\section{Interaction between antibiotic use and MS4A2 rs569108 on eczema}

Table 4 shows that children with both antibiotic use and MS4A2 rs569108 GG genotype were more likely to develop eczema than those without antibiotic use and GG homozygote $(P=1.49 \mathrm{E}-02, \mathrm{OR}=6.24)$, and also more likely to develop eczema than those with only antibiotic use or GG genotype (OR = 6.24 VS. 2.04 or 4.68).

\section{Discussion}

In this study, MS4A2 rs569108 GG genotype and antibiotic use were found solely associated with eczema in early life, and they interacted with each other to enhance the risk of developing the disease. This is the first report of gene-environment interactions between rs569108 and antibiotic use on childhood eczema.

Our study is the first to report an independent association of MS4A2 rs569108 GG homozygote with eczema in two-year-old children. This polymorphism has been reported significantly associated with histamine release from basophils [19], which may induce atopic eczema

Table 4 Interaction between antibiotic use and MS4A2 rs569108 on eczema

\begin{tabular}{llllll}
\hline Antibiotic use & rs569108 & $\begin{array}{l}\text { Eczema } \\
\mathbf{n}(\%)\end{array}$ & $\begin{array}{l}\text { Non-eczema } \\
\mathbf{n}(\%)\end{array}$ & $\boldsymbol{P}_{\text {value }}{ }^{\mathbf{a}}$ & OR(95\%Cl) \\
\hline- & AA/AG & $67(39.9 \%)$ & $251(59.1 \%)$ & & 1 \\
- & GG & $5(3.0 \%)$ & $4(0.9 \%)$ & 0.03 & $4.68(1.22,17.92)$ \\
+ & AA/AG & $91(54.2 \%)$ & $167(39.3 \%)$ & 0.00 & $2.04(1.41,2.96)$ \\
+ & GG & $5(3.0 \%)$ & $3(0.7 \%)$ & 0.01 & $6.24(1.46,26.79)$ \\
\hline
\end{tabular}

$O R$ odds ratio, $\mathrm{Cl}$ confidence interval

${ }^{a} P$ Values for $X^{2}$ tests 
[20]. Our study also confirmed the independent effect of antibiotic use on risk of childhood eczema, consistent with previous reports [21-24]. Early life exposure to antibiotics may have adverse effects on the neonatal gut microbiome and adversely affect the development of the infant immune system, leading to childhood atopic diseases [25]. How the polymorphism in the MS4A2 gene interacts with antibiotic exposure in early life to increase risk of eczema remains unknown. Future studies are needed to investigate the biological interactions between them.

There are some limitations in this research. First, only 597 children completed two-year follow-up in this study, which had a small sample size and a short follow-up duration. Larger sample size and long-term follow-up are needed in future. Second, only four genes (i.e. IL13, IL4, MS4A2 and IL4RA) were chosen as candidate genes. However, the four genes are susceptible genes of atopy [7-12] replicated in more than ten different populations [13]. In our further study, more genes and SNPs associated with atopy and eczema should be included. Third, environmental exposures were evaluated by self-reported questionnaire, which may underestimate the associations of certain environmental exposures. Direct measurement of certain environmental exposures is needed in future. Fourth, assessment of eczema was based on parentalreported symptoms in this birth cohort study. $28.14 \%$ (168/597) of the subjects developed eczema, and the prevalence data was similar with that reported in another study [26]. Fifth, replications of the findings in other populations are needed in future studies.

\section{Conclusions}

This study suggests that MS4A2 rs569108 polymorphism and antibiotic use were independently associated with eczema, and they interacted with each other to increase the risk of developing the disease in Chinese Han toddlers, which still need long-term follow-up along with functional and replication studies.

\section{Abbreviations \\ SNPs: Single-nucleotide polymorphisms; OR: Odds ratio; rs: Reference SNP; $\mathrm{Cl}$ : Confidence interval}

\section{Acknowledgements}

We would like to thank all the participants and their parents.

\section{Authors' contributions}

$\mathrm{LH}, \mathrm{JHZ}$ and $\mathrm{JZ}$ conceived and designed the study. QC and QHL collected and processed the specimens. $\mathrm{LH}, \mathrm{LWW}$ and $\mathrm{QHL}$ did the measurement of the specimens. $\mathrm{LH}, \mathrm{QHL}, \mathrm{QC}, \mathrm{YFG}$ and $\mathrm{RHC}$ sorted out the questionnaire data. $\mathrm{LH}, \mathrm{RXJ}$ and $\mathrm{QHL}$ conducted the statistical analysis. $\mathrm{LH}$ drafted the manuscript. RXJ, LWW and JHZ reviewed and edited the manuscript. All authors read and approved the manuscript.

\section{Funding}

This study was funded by the Youth Program of National Nature Science Foundation of China (No. 81900018), the Project for Innovation Teams in Local High Level Universities in Shanghai, and the State Key Program of
National Nature Science Foundation of China (No. 81530086). The funding body had no role in the design of the study and collection, analysis, and interpretation of data and in writing the manuscript.

\section{Availability of data and materials}

The datasets generated and analyzed during the current study are not publicly available due to ethical concerns, but are available from the corresponding authors on reasonable request.

\section{Declarations}

\section{Ethics approval and consent to participate}

Written informed consent was obtained from parents and / or legal guardians for all the subjects who are under 16. This study was approved by the Ethics Committees of the two participating hospitals, Xinhua Hospital and the International Peace Maternity \& Child Health Hospital (approval number: XHEC-C-2012-003), and conducted according to the principles in the Declaration of Helsinki.

\section{Consent for publication}

Not applicable.

\section{Competing interests}

The authors declare that they have no competing interests.

\section{Author details}

${ }^{1}$ Department of Pediatric Pulmonology, Xin Hua Hospital, Shanghai Jiao Tong University School of Medicine, 1665 Kongjiang Road, Shanghai 200092, China. ${ }^{2}$ Ministry of Education-Shanghai Key Laboratory of Children's Environmental Health, Xin Hua Hospital, Shanghai Jiao Tong University School of Medicine, 1665 Kongjiang Road, Shanghai 200092, China.

${ }^{3}$ Department of Dermatology, Xin Hua Hospital, Shanghai Jiao Tong University School of Medicine, 1665 Kongjiang Road, Shanghai 200092, China.

Received: 20 April 2021 Accepted: 30 June 2021

Published online: 14 July 2021

\section{References}

1. Deckers IA, McLean S, Linssen S, et al. Investigating international time trends in the incidence and prevalence of atopic eczema 1990-2010: a systematic review of epidemiological studies. PLoS One. 2012;7:e39803.

2. Weidinger S, Beck LA, Bieber T, Kabashima K, Irvine AD. Atopic dermatitis. Nat Rev Dis Primers. 2018;4:1

3. Bisgaard $\mathrm{H}$, Simpson A, Palmer CN, et al. Gene-environment interaction in the onset of eczema in infancy: filaggrin loss-of-function mutations enhanced by neonatal cat exposure. PLoS Med. 2008:5:e131.

4. Jabbar-Lopez ZK, Craven J, Logan K, et al. Longitudinal analysis of the effect of water hardness on atopic eczema: evidence for gene-environment interaction. Br J Dermatol. 2020;183:285-93.

5. Burrows $B$, Martinez FD, Halonen M, et al. Association of asthma with serum IgE levels and skin-test reactivity to allergens. N Engl J Med. 1989;320:271-7.

6. Williams HC. Clinical practice. Atopic dermatitis. N Engl J Med. 2005;352: 2314-24.

7. Wang M, Xing ZM, Lu C, Ma YX, Yu DL, Yan Z, et al. A common IL-13 Arg130GIn single nucleotide polymorphism among Chinese atopy patients with allergic rhinitis. Hum Genet. 2003;113:387-90.

8. Hunninghake GM, Soto-Quirós ME, Avila L, Su J, Murphy A, Demeo DL, et al. Polymorphisms in IL13, total IgE, eosinophilia, and asthma exacerbations in childhood. J Allergy Clin Immunol. 2007;120:84-90.

9. Liu X, Beaty TH, Deindl P, Huang SK, Lau S, Sommerfeld C, et al. Associations between specific serum lgE response and 6 variants within the genes IL4, IL13, and IL4RA in German children: the German multicenter atopy study. J Allergy Clin Immunol. 2004;113:489-95.

10. Liu X, Beaty TH, Deindl P, Huang SK, Lau S, Sommerfeld C, et al. Associations between total serum lgE levels and the 6 potentially functional variants within the genes IL4, IL13, and IL4RA in German children: the German multicenter atopy study. J Allergy Clin Immunol. 2003;112:382-8.

11. Zhu S, Chan-Yeung M, Becker AB, Dimich-Ward H, Ferguson AC, Manfreda J, et al. Polymorphisms of the IL-4, TNF-alpha, and Fcepsilon Rlbeta genes and 
the risk of allergic disorders in at-risk infants. Am J Respir Crit Care Med. 2000;161:1655-9.

12. Hizawa N, Yamaguchi E, Jinushi E, Kawakami Y. A common FCER1B gene promoter polymorphism influences total serum lgE levels in a Japanese population. Am J Respir Crit Care Med. 2000;161:906-9.

13. Ober C, Hoffjan S. Asthma genetics 2006: the long and winding road to gene discovery. Genes Immun. 2006;7:95-100.

14. Worldwide variation in prevalence of symptoms of asthma, allergic rhinoconjunctivitis, and atopic eczema: ISAAC. The international study of asthma and allergies in childhood (ISAAC) Steering Committee. Lancet. 1998:351:1225-32.

15. Chen $Y Z$, Zhao TB, Ding $Y$, et al. A questionnaire based survey on prevalences of asthma, allergic rhinitis and eczema in five Chinese cities (ISAAC study). Chin J Pediatr. 1998;36:352-5.

16. Williams HC, Jburney PG, Hay RJ, et al. The U.K. working Party's diagnostic criteria for atopic dermatitis. I. Derivation of a minimum set of discriminators for atopic dermatitis. Br J Dermatol. 1994;131:383-96.

17. Hua L, Zuo XB, Bao YX, Liu QH, Li JY, Lv J, et al. Four-locus gene interaction between IL13, IL4, FCER1B, and ADRB2 for asthma in Chinese Han children. Pediatr Pulmonol. 2016;51:364-71.

18. Sharma V, Michel S, Gaertner V, et al. A role of FCER1A and FCER2 polymorphisms in IgE regulation. Allergy. 2014;69:231-6,

19. Kim YK, Oh SY, Oh HB, et al. Coding single nucleotide polymorphism in the high-affinity immunoglobulin $\mathrm{E}$ receptor $\mathrm{b}$ chain (FcepsilonRl-beta) gene is associated with immunoglobulin $E$ receptor-mediated histamine release from basophils. Clin Exp Allergy. 2002;32:751-5.

20. Wehner J, Neuber K. Staphylococcus aureus enterotoxins induce histamine and leukotriene release in patients with atopic eczema. Br J Dermatol. 2001; 145:302-5.

21. Tsakok T, McKeever TM, Yeo L, Flohr C. Does early life exposure to antibiotics increase the risk of eczema? A systematic review. Br J Dermatol. 2013;169:983-91.

22. Singh S, Sharma BB, Salvi S, et al. Allergic rhinitis, rhinoconjunctivitis, and eczema: prevalence and associated factors in children. Clin Respir J. 2018;12: $547-56$

23. Torley D, Futamura M, Williams HC, Thomas KS. What's new in atopic eczema? An analysis of systematic reviews published in 2010-11. Clin Exp Dermatol. 2013;38:449-56.

24. Wohl DL, Curry WJ, Mauger D, Miller J, Tyrie K. Intrapartum antibiotics and childhood atopic dermatitis. J Am Board Fam Med. 2015;28:82-9.

25. Lamont RF, Møller Luef B, Stener JJ. Childhood inflammatory and metabolic disease following exposure to antibiotics in pregnancy, antenatally, intrapartum and neonatally. F1000Res. 2020;9:F1000 Faculty Rev-144.

26. Cai J, Liu W, Hu Y, Zou Z, Shen L, Huang C. Associations between home dampness-related exposures and childhood eczema among 13,335 preschool children in Shanghai, China: a cross-sectional study. Environ Res. 2016;146:18-26.

\section{Publisher's Note}

Springer Nature remains neutral with regard to jurisdictional claims in published maps and institutional affiliations.

Ready to submit your research? Choose BMC and benefit from:

- fast, convenient online submission

- thorough peer review by experienced researchers in your field

- rapid publication on acceptance

- support for research data, including large and complex data types

- gold Open Access which fosters wider collaboration and increased citations

- maximum visibility for your research: over $100 \mathrm{M}$ website views per year

At BMC, research is always in progress.

Learn more biomedcentral.com/submissions 